\title{
Some geo-botanic features of the Kurile Islands
}

\begin{abstract}
Results of many years research of geo-botanic of the Kurile Islands are presented in article. Vegetation spatial structure of the Kurile Islands is conditioned by complex interactions of endogenous and exogenous factors. Meridional extension for almost $1200 \mathrm{~km}$ determines a significant climatic differenciation within archipelago. It is resulted in changes of vertical vegetation zones in the different regions of Kurile Islands. System of hot and cold currents in the adjacent sea water is the factor of asymmetry of vegetation. Special traits of archipelago are determined by the volcanic activity
\end{abstract}

Keywords

Kurile Islands $\bullet$ vegetation $\bullet$ climate $\bullet$ volcanism $\bullet$ vegetation asymmetry

(C) University of Warsaw - Faculty of Geography and Regional Studies

\section{Kirill Ganzei}

Pacific Geographical Institute of Far Eastern

Branch of Russian Academy of Sciences

Russia

e-mail: geo2005.84@mail.ru

Received: 17 November 2014

Accepted: 30 March 2015

\section{Introduction}

Formation of island geosystems happens under the influence of many factors. First of them is degree of their isolation from continents and other islands. Results of studying of vegetation spatial structure show not only modern features of the factors which form natural environment nowadays, but also their influence on nature in the past.

In this paper, both the modern structure of vegetation of the Kurile Islands and the influence of global, regional and local factors on the spatial differentiation of vegetation are shown. Kurile Islands are characterized by the various physico-geographical conditions, which are defined by the prevalence of the mountain relief, islands isolation, considerable meridian extension (more than $1200 \mathrm{~km}$ long), barrier character of the location between the Sea of Okhotsk and Pacific Ocean and intensive geodynamic processes. These peculiarities had created the conditions for complicated landscape structure formation.

Results of this work are based on the field materials which were collected during complex scientific expeditions (2002-2011) made together with Pacific Geographical Institute (Vladivostok, Russia) and Institute of Marine Geology and Geophysics (Yuzhno-Sakhalinsk, Russia) of Far Eastern Branch of Russian Academy of Sciences and within the frame of Kurile Biocomplexity Project (University of Washington, Seattle, USA). Field works included installation of the main, mapping and base observing posts. Full description of the geomorphological structure of the territory, character and peculiarities of lithogenous composition, qualitative and quantitative descriptions of soil horizons were done. Vegetation description included the analysis of trees crowns, trunks, root systems, scrubs, subshrubs, grasses.
During the research were used the remote sensing data from LANDSAT ETM+ (2000-2013) and ASTER (2009-2011), materials of aerial photography, topographic maps of 1:100 000, 1:200 000 scale, archive and published materials, thematic maps (geological, geomorphological, volcano-geomorphological, soil), forest management materials. These materials were used for landscape mapping of Kurile Islands in scale 1:200 000.

\section{Regional physico-geographical characteristics}

The Kurile Islands stretch from north-east to south-west for $1200 \mathrm{~km}$ from Kamchatka Peninsula to Hokkaido Island. The islands row includes the Big and Lesser Islands Archipelago, that have more than $30 \mathrm{big}$ islands and considerable number of small islands and rocks. The chain of islands is divided into 3 regions: Southern (the Lesser Kuriles, the islands of Kunashir, Iturup, Urup, Chernie Brat'ya), Middle or Central (from Simushir Island to Raikoke Island) and Northern (from the Shiashkotan to Shumshu Island) (Fig. 1).

The Archipelago of the Kurile Islands is on the junction of the giant Earth's morphostructures - Eurasian continent and Pacific Ocean. Modern block folding structure of the islands was formed during the end of Pliocene - beginning of Pleistocene (Aprodov 1982). There are 25 large volcanoes on the Big Kurile Arc. Formation of all the volcanoes was characterized by large lava outflows of andesite, sometimes - andesite-basalt and basalt composition (Newest... 2005). Strong volcanoes eruptions are happening on average every 33 years on the Kurile Islands, moderately strong are taking place every 22 years, moderate - every 11 years and weak - every 1-5 years (Rybin et al. 2004). 


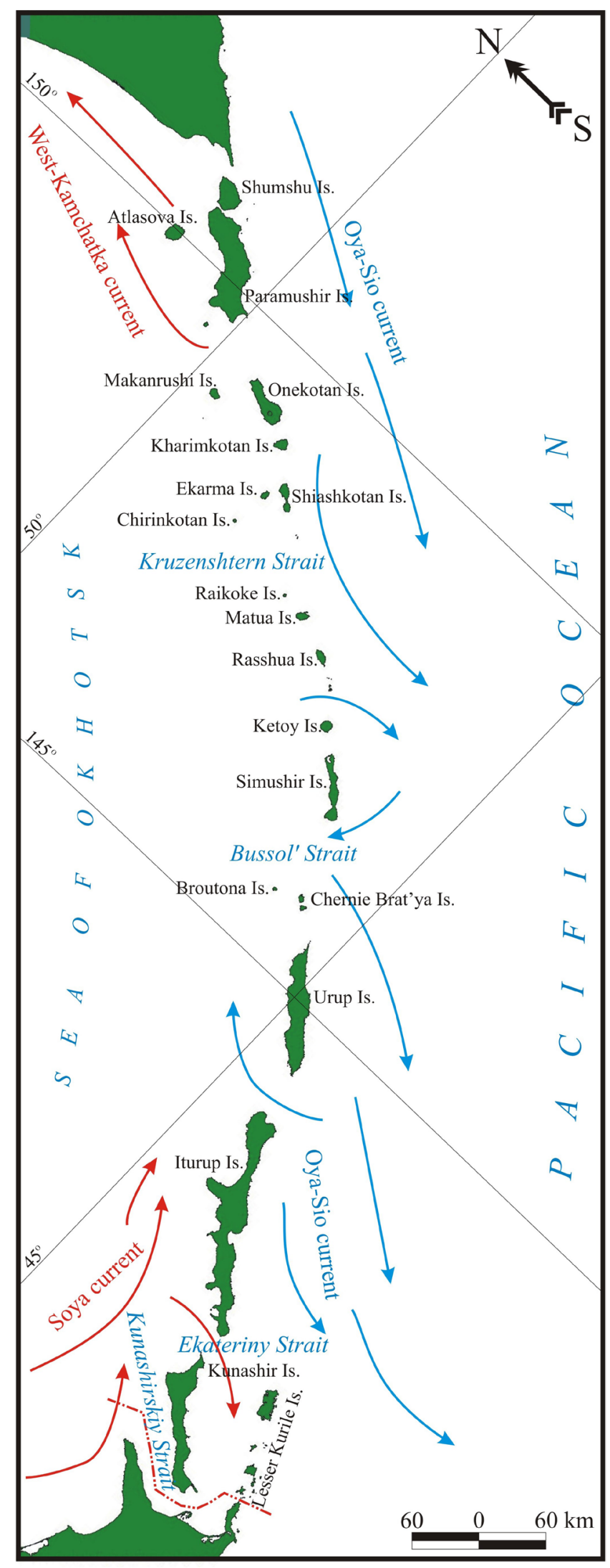

Figure 1. Kurile Islands 
The main factor of the relief formation on the Kurile Islands is volcanogenic processes. More than $44 \%$ area of islands have been formed by volcanogenic landscapes, $30.5 \%$ - by denudation-accumulative, $22.04 \%$ - by denudation-volcanogenic (Ganzei 2009)

Meridional extension of the Kurile Islands for almost 1200 $\mathrm{km}$ determines a significant climatic differenciation within archipelago. The Siberian anticyclone and the Aleutian cyclone formed in the winter-season have strong impact on the climate of the region. They form the winter monsoon with strong northwest winds and pronounced marine climate features. During summer period the area of low atmospheric pressure is formed over the continent, while the Pacific subtropical anticyclone starts moving towards middle latitudes, which results in formation of the summer monsoon with winds from the south and southeast prevalence, which bring wet sea air (Atlas... 1967). The main climatic characteristics are shown in Table 1.

Modern soil cover of the Kurile Islands was formed under the influence of two main factors: volcanogenic and biogenic. The main trait of the soils there is their lamination, under development of soils profile, presence of buried layers, fine texture, high water permeability, propensity to erosion. Soil formation is affected by pyroclastic deposits (ash, pumice), and alluvial sands or clay loam on low isthmuses (Gladkova \& Butovets 1988).

There are 2 floristic zones on the Kurile Islands (Barkalov 2002). The group of islands from Shumshu to Simushir is included into the Circumboreal area, which includes 2 floristic regions. The North Kurile region is bordered by the First Kurile (in the north) and Kruzenshtern (in the south) straits. The alder and mountain pine are prevailing and some Arctic species belong to flora there. American flora representatives are also typical for this region. The Middle Kurile region is limited by the Kruzenstern (in the north) and Bussol (in the south) straits. This region is close to the North Kurile region but has some elements of the East Asian flora: bamboo Sasa and stone birch.

The East Asian floristic area is located south of the Bussol strait and divided into 3 regions. The Urupskiy region consists of the islands: Chernie Brat'ya, Urup and Iturup to the north of Vetrovoy Isthmus. The region is close to the South Kurile, but the species of the Middle Kurile region play the main role. For the South Kurile region (Kunashir Island and Iturup to the south of Vetrovoy Isthmus), large amount of thermophytes "Japanese" or East Asian (spruce and fir, broadleaved forests) - is characteristic. The Lesser Kurile region: mountain pine is ecologically replaced by juniper. Oak, kalopanax, magnolia and some others are absent. There is no forest vegetation on the islands to the south from Shikotan Island (Barkalov 2002).

\section{Interaction of environmental factors}

Vegetation spatial structure of the Kurile Islands is conditioned by complex interactions of endogenous and exogenous factors. The comprehensive scheme of interactions of environmental factors, with the indication of results of their influence on geosystems of the Kurile Islands, has become one of the main results of research work (Fig. 2).

Regional climatic conditions and geomorphological structure of the islands determine formation of the vertical (altitude) vegetation zones (belts) and asymmetric spreading of the vegetation on the slopes of different exposure (aspect). Features of spatial structure of geosystems of the Kurile Islands were formed as a result of environment development in the Holocene (Razjigaeva, Ganzey, Grebennikova et al. 2013). A zoogenic natural factor has influenced especially isolated island territories: geochemical characteristics of a soil cover was changed in a result of activity of colonial birds.

The group of endogenous factors includes, first of all, present and Holocene volcanism, seismicity and tsunami. Mainly, tsunami wave formation depends directly upon the character of seismic movements of Earth crust and volcanism occurrence. Exogenous factors sometimes affect the character of endogenous processes activity and vice versa. E.g., the delivery of the products of volcanic eruptions depends on the wind direction.

\section{Vertical vegetation zones}

The extent of the Kurile Islands determines the differentiation of climatic conditions within the archipelago what results in the spatial changeability of its vegetation. There is an expected increase of the altitude intervals of the vertical vegetation belts to the south, and also appearance of the new vertical vegetation zones there (Barkalov 2002). Geomorphological structure also depends on the altitude. With the rise of the altitude a decrease of heating and humidity of the territory is observed. It is worth

Table 1. Climatic indexes of the Kurile Islands (Reference book... 1966; 1968)

\begin{tabular}{|c|c|c|c|c|c|c|c|c|c|}
\hline \multirow[b]{2}{*}{ Climatic index } & \multicolumn{9}{|c|}{ Station name (Island) } \\
\hline & 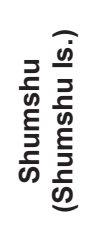 & 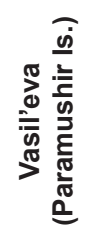 & 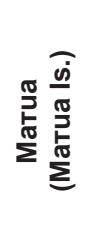 & 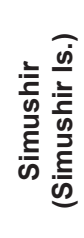 & 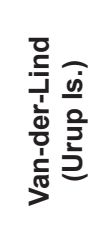 & 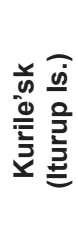 & 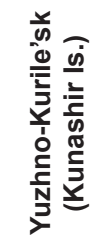 & 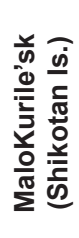 & 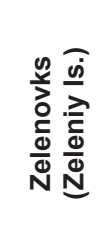 \\
\hline $\begin{array}{l}\text { Average annual air } \\
\text { temperature, }{ }^{\circ} \mathrm{C}\end{array}$ & 1.8 & 1.6 & 1.8 & 2.8 & 2.7 & 4.4 & 5 & 5.2 & 5.2 \\
\hline $\begin{array}{c}\text { Average annual air humidity, } \\
\%\end{array}$ & 85.1 & 86.5 & 85.2 & 85.3 & 86.5 & 81.5 & 82 & 82.8 & 83.6 \\
\hline Annual precipitation total, $\mathrm{mm}$ & 1245 & 1376 & 1223 & 1610 & 1015 & 1040 & 1255 & 1240 & 1020 \\
\hline $\begin{array}{l}\text { Average amount of days with } \\
\text { blizzards a year }\end{array}$ & 141 & 154 & 138 & 114 & No data & 121 & No data & 76 & No data \\
\hline $\begin{array}{c}\text { Average amount of foggy } \\
\text { days a year }\end{array}$ & 130 & 179 & 205 & 171 & No data & 95 & 161 & 139 & No data \\
\hline
\end{tabular}




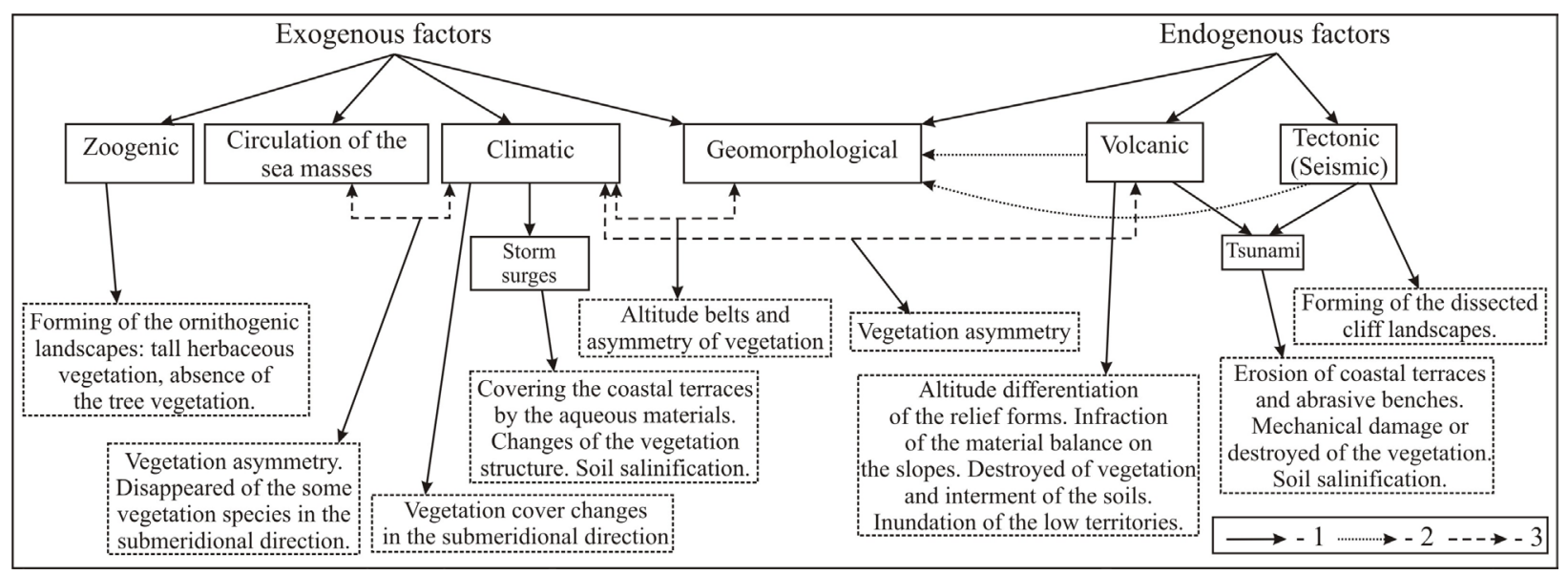

Figure 2. Factors of environmental differentiation of the Kurile Islands: 1 - bounds and result of different level factors manifestation; 2 - bounds of one level factors; 3 - interaction of different factors

noting, that there is an unclear character of the altitude belts within island territories of the north-western Pacific Ocean (Ivanov 2005) because of the smaller gradients of the temperatures with the altitude rise. These gradients comprise $0,6^{\circ} \mathrm{C}$ for $100 \mathrm{~m}$ for the continental landscapes and only $0,4^{\circ} \mathrm{C}$ for $100 \mathrm{~m}$ for the island territories.

Together with this, vertical vegetation zones (altitude belts) are presented on almost all the Kurile Islands. On the Northern and Middle Kurile Islands the altitude belts are not as on the South Kuriles. For the group of islands from Paramushir in the north to Matua in the south, the formation of vegetation belts with absolute domination of alder thickets, covering the slopes of the mountain ranges and volcanoes, is very typical. On the Paramushir and Atlasova islands, the alder thickets form a vertical zone which stretches from the seashore to the altitudes of 850-900 m, on the Onekotan and Shiashkotan islands - up to $550-600 \mathrm{~m}$, on Matua Island - up to $400 \mathrm{~m}$. On these islands, mountain pine thickets can be found but it plays inferior role (Table 2). Mountain pine thickets was also noted within alder thickets and sometimes it dominates on slopes, nevertheless, it is absent on small island volcanoes (e.g., on Matua Island). On the tops and near the top surfaces, mainly those which were not changed by the volcanic activity, mountain-tundra vertical zone (altitude belt) was formed. On Paramushir Island, this vegetation belt starts from the altitude of 850-900 m and higher. Maximum spread of tundra-mountain belt is recorded on the Fussa volcano (1772 m). It should be emphasized, that mountain tundra and scrubs have occupied $83 \%$ area of North Kurile Islands, and more than $53 \%$ of area on Middle Kurile Islands.

Formation of the altitude belt with fragmentary lithomorphic lichen or without vegetation cover can be often observed on the tops of active volcanoes. Nevertheless, its development is directly connected with a volcanic factor.

In the lower parts of the slopes of the islands from Rasshua to Simushir, the birch-alder thickets appear, however, alder groves are still dominating. On the islands of Rasshua and Simushir, altitude belt of stone birch and alder can be found starting from the sea shore up to the altitude of $400 \mathrm{~m}$, and on Ketoy Island - up to $600 \mathrm{~m}$. Only on Urup Island, the birch-alder belt predominates, forming a zone from the seashore to the altitude of 1050-1150 m (Table 2). On the Urup Island stone birch forests are also widespread. It is also typical for the north part of Iturup Island, where stone-birch forests occupy the area from the seaside to the altitude of $700-800 \mathrm{~m}$. On Iturup Island, next to the tops
Table 2. Intervals of the altitude vegetation belts on the Kurile Islands

\begin{tabular}{|c|c|c|}
\hline Islands & $\begin{array}{c}\text { Altitude } \\
\text { vegetation belts }\end{array}$ & $\begin{array}{l}\text { Altitude intervals } \\
\text { of distribution }(\mathrm{m})\end{array}$ \\
\hline \multirow{2}{*}{$\begin{array}{l}\text { Paramushir - } \\
\text { Atlasova }\end{array}$} & Alder thickets & $0-900$ \\
\hline & Moutain tundra & $850-1700$ \\
\hline \multirow{2}{*}{$\begin{array}{l}\text { Onekotan - } \\
\text { Shiashkotan }\end{array}$} & Alder thickets & $0-600$ \\
\hline & Mountain tundra & Fragmentary \\
\hline \multirow{2}{*}{ Matua } & Alder thickets & $0-400$ \\
\hline & $\begin{array}{c}\text { Fragmentary } \\
\text { lithomorphic lichen }\end{array}$ & $400-1400$ \\
\hline \multirow{3}{*}{ Rasshua } & Birch-alder & $0-400$ \\
\hline & Mountain pine & $400-760$ \\
\hline & $\begin{array}{c}\text { Fragmentary } \\
\text { lithomorphic lichen }\end{array}$ & $760-940$ \\
\hline \multirow{3}{*}{ Ketoy } & Birch-alder & $0-600$ \\
\hline & Mountain pine & $600-720$ \\
\hline & $\begin{array}{c}\text { Fragmentary } \\
\text { lithomorphic lichen }\end{array}$ & $720-990$ \\
\hline \multirow[b]{2}{*}{ Simushir } & Alder thickets & $0-900$ \\
\hline & $\begin{array}{c}\text { Fragmentary } \\
\text { lithomorphic lichen }\end{array}$ & $900-1350$ \\
\hline \multirow{2}{*}{ Urup } & Birch-alder & $0-1150$ \\
\hline & Mountain pine & $1150-1300$ \\
\hline \multirow{2}{*}{$\begin{array}{c}\text { Northern part } \\
\text { of } \\
\text { Iturup }\end{array}$} & Stone birch & $0-750$ \\
\hline & Mountain pine & $750-950$ \\
\hline \multirow{4}{*}{$\begin{array}{l}\text { Sothern part of } \\
\text { Iturup }\end{array}$} & Oak-alder & $0-300$ \\
\hline & Larch & $300-400$ \\
\hline & Stone birch & $300-850$ \\
\hline & Mountain pine & $850-1600$ \\
\hline \multirow{3}{*}{ Kunashir } & Pine-fir & $0-750$ \\
\hline & Stone birch & $750-1100$ \\
\hline & Mountain pine & $1100-1200$ \\
\hline
\end{tabular}


and on the tops of volcanoes and mountain ranges the zone of mountain pine thickets is present and starts from the altitude of 650-700 m.

Oak-alder and larch forests within the interval of 250-400 m are formed south of the northern foot of Grozniy mountain range on Iturup Island. Oak-alder forests can be found only on the plains, foothills and valleys and occupy $8,38 \%$ area of island (266 sq. km.). Larch forests grow on the slopes of mountain ranges and volcanoes and cover $116,52 \mathrm{sq}$. $\mathrm{km}$ but do not form continuous altitude belt as the stone birch and alder do.

On the slopes of the Stokap volcano, lower vegetation belt is formed by pine-fir forests which dominate on Kunashir Island $(52,28 \%$ area of island) from the seashore to the altitude of 650 $750 \mathrm{~m}$. The birch-alder forests reach to the upper hypsometrical level, to the interval of $700-1250 \mathrm{~m}$ (Table 2).

Totally on Kurile Islands parvifoliate forests (31.29\%) and mountain tundra and scrubs (39.25\%) are dominate. It should be emphasized that only $0.52 \%$ of the Kurile Islands area undergoes a human influence. There are only 8 settlements on the 4 biggest islands of the arc. Population of Kurile Island is 19000 on the area more than 10000 sq.km.

\section{Vegetation asymmetry}

Monsoonal circulation of continental and oceanic air masses with the prevalence of north-east winds during winter period and south-west winds during summer is typical for the region of Kurile Islands. This circulation changes the humidity character and temperature on the slopes of different aspects and leaves its trace on formation of climatic asymmetry of vertical vegetation belts within the islands. A system of sea currents around the archipelago is the other factor of asymmetry of vegetation.

The prevalence of the mountain pine thickets and communities with them on the eastern slopes can be observed on all the Kurile Islands. The exceptions are the Iturup and Kunashir islands, where this pattern can less clear due to the higher hypsometric level of mountain pine thickets and peculiarities of climatic conditions. The reason of asymmetric distribution of mountain pine thickets on the majority of islands is the prevalence of northwest winds, which bring cold air masses, during winter season. Apart from that, we can not exclude the impact of snow cover formation on the islands, because the thickness of the snow layer is very important for the mountain pine (Manko \& Sidelnikov 1989).
Another reason of asymmetry is connected with the high need of mountain pine in sun. Extrusion of mountain pine from the slopes of north exposition to the southern slopes by alder wood was noted by Y.I Manko and A.N. Sidelnikov (1989) in the region of Tolbachik volcano on the Kamchatka Peninsula.

Sea currents have special influence on the character of asymmetric distribution of the vegetation of the South Kurile Islands. First of all, it is necessary to note the impact of the warm current - Soya, which reaches central part of Iturup Island and the South-Kurile strait through the Kunashirskiy and Ekateriny straits, forming higher temperatures of the water in comparison with the waters of the Pacific Ocean (Fig. 1). There are no severe frosts in the South Kuriles region what is connected with the influence of warm Pacific air masses. At winter time high anomalous temperature of oceanic waters is registered because of the mixing of cold waters with warm water of north-east branch of Kuroshio and Sangarskoe currents from the Pacific Ocean and Soya current from Sea of Okhotsk (Vlasova \& Polyakova 2004).

The impact of the cold Oya-Sio current is really big during summer time, when air masses which cross it get cold and bring mists to the northern shore of the islands. Meridional mountain ranges of Iturup and Kunashir Islands protect west coast from these air masses.

General impact of the complex circulatory processes in waters and their impact on air masses formation determine asymmetry in distribution of vegetation belts with thermophile vegetation. Discrepancy of vegetation development between west and east slopes estimate 8-25 days (Barkalov \& Eremenko 2003). As a result, forests with domination of oak and alder with a share of maple and elm are located only on the west seaside of Kunashir and Iturup Islands. On the figure 3 the typical landscape profile of Kunashir Island from Sea of Okhotsk to Pacific Ocean is shown. Northern limit of oak-elm forests distribution almost matches the end of Soya current, what determines their maximal distribution northwards - middle part of Iturup Island. On Kunashir Island, oak and alder forests with a share of maple and elm and some other species can be found in river valley. On Iturup Island, they are reaching to volcanic plateaus, terraces and plains of different genesis. Thus, asymmetric formation of the vegetation is connected with expositional climatic differences between western and eastern macro-slopes.

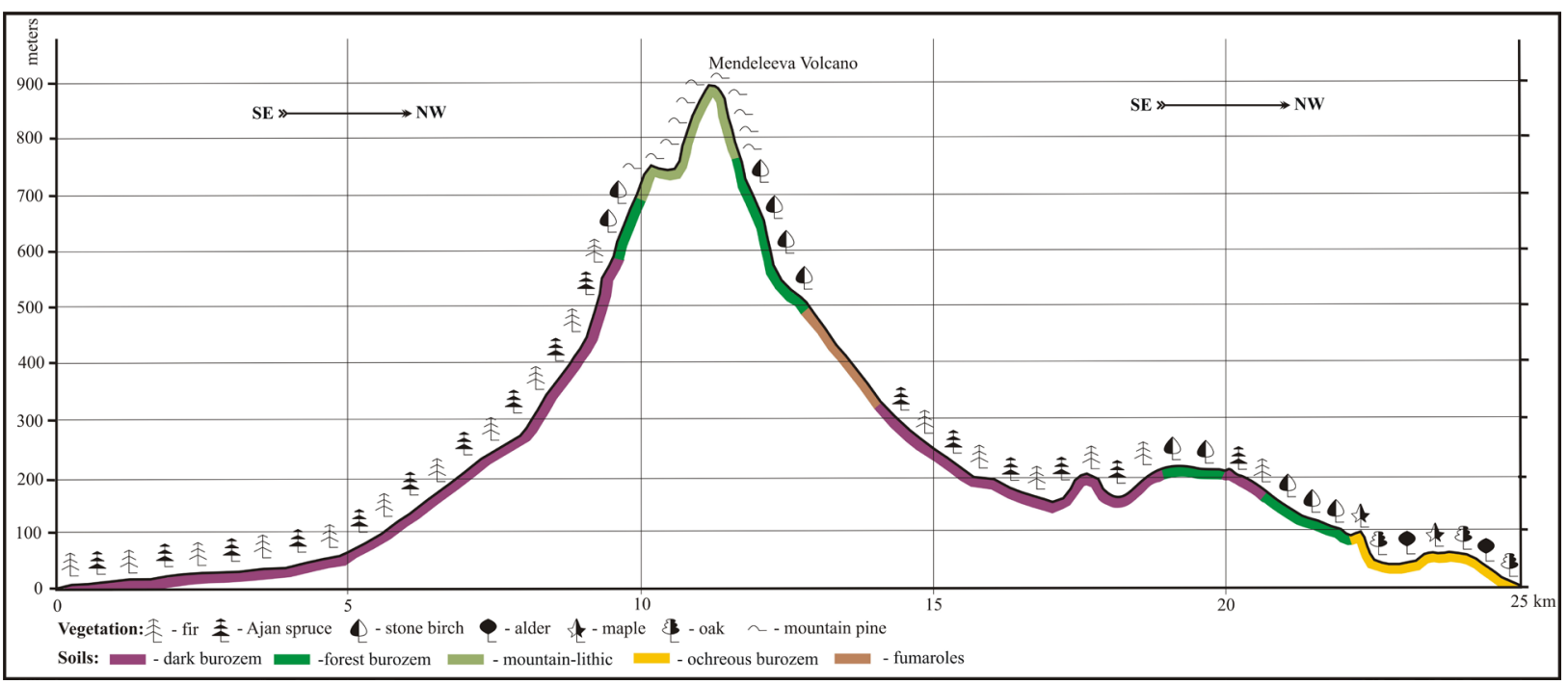

Figure 3. Landscape profile of Mendeleeva volcano (central part of Kunashir Island) 


\section{Volcanic influence on vegetation}

Total or partial absence of vegetation cover on the slopes of stratovolcanoes, lava streams, adjacent to the stratovolcano cones and in crater lowlands is typical for the majority of active volcanoes of the Kurile Islands. During the eruptions, many factors influence on the vegetation. Volcanic materials also change geochemical characteristics of soil. Nevertheless, in a number of cases, penetration of eruption products lead to the sharp growth of plants phytomass in the soil cover, what was demonstrated by Yu.I. Manko and A.N. Sidelnikova (1989) on the example of the Kamchatka Peninsula.

The unequal distribution of volcanic eruption products is connected with the dominating wind direction which provokes asymmetry in vegetation cover spreading. Thus, on Chikurachki volcano (Paramushir Island), south-east wind was making the eruption products to drift to the north-west slopes (Belousov et al. 2003). As a result, thinned out grass meadows are prevailing there and alder groves are widespread on the opposite slopes. Accumulation of volcanic material, along with its dissemination, takes place on the nearest uplands' slopes exposed to southeast where thinned out grass meadows grows on primitive soddy soils.

Such a pattern was noted for Tyaya volcano (Kunashir Island) and Berutarube volcano (Iturup Island) during the formation of altitude vegetation belts asymmetry. As a result of Tyatya volcano eruption in 1973, altogether with Otvazhniy crater formation on the south-east slope, the matter was discharged on the slope expose to south-east under the influence of northwest winds. That resulted in distortion of vegetation altitude belts structure, manifested in the spreading of alder-birch forests to the shoreline, while on the north-west slope they occupy the altitudes between 560-1200 meters. We also cannot exclude the impact of the eruption of 1812 on the asymmetry of altitude belts. Identical process was described for Berutarube volcano, where the distortion of altitude belts is observed: on the southeast slope birch-alder forest reaches the seashore. There are no historical evidences of this volcano eruption, but we can assume that the reason of it is the ancient lava flow or pyroclastic material outburst to the south-east direction (Ganzei 2008).

There is a total extinction of some plant species observed under the volcanism impact on the whole islands or their parts. Mountain pine thickets and stone birch absence in the zone with high volcanic activity. These vegetation communities are replaced by alder groves on the Kamchatka Peninsula because the latter are more competitive (Egorova \& Khomentovskiy 1988). These authors had noted a high vulnerability of mountain pine thickets and birch woods to the volcanic impact. Total destruction of mountain pine thickets groves is observed when the thickness of the deposited volcanic material is $15 \mathrm{~cm}$, for stone birch this number is $20 \mathrm{~cm}$, while some alder species reproduce when volcanogenic material layer is $70-80 \mathrm{~cm}$ thick (Manko \& Sidelnikova 1989; Dirksen \& Dirksen 2006).

During the field research on the islands, a full absence of mountain pine thickets was noted in the areas of recent active volcanic activity. In the first place, it is true for the following volcanic islands: Atlasova, Anitsiferova, Kharimkotan, Ekarma, Chirinkotan, Raykoke, Matua, Ushishir, Chernie Bratya,
Broutona. Intensity of volcanic eruptions is very high on the islands what is confirmed by many volcanogenic materials in sedimentary cover. Different communities formed by alder groves are dominating in the vegetation of the majority of the islands (apart from Chirinkotan, Raikoke, Ushishir and Chernie Brat'ya where there no woods at all).

The absence of the mountain pine thickets on the Lesser Kurile Islands is caused by the impact of the volcanoes, located on the Kunashir, Iturup and Hokkaido Islands. Important factor of non-restoration of the mountain pine thickets is isolation of small island groups and absence of preserved bushes as a seed source. On the large Kurile Islands (Iturup, Kunashir, Paramushir, Urup, Simushir) the restoration is possible from separated clumps in the areas remote from the zones of volcanic impact. Identical process of mountain pine and stone birch restoration could have been traced on the Kamchatka Peninsula during formation of Kurile Lake 7600 years ago (Dirksen \& Dirksen 2006) and Tolbachik volcano eruption (Manko \& Sidelnikova 1989).

Interesting volcanism impact on vegetation is noted on Simushir Island, where lengthwise asymmetry of vegetation is formed. Large-scale eruptions took place in the region of Goryashaya Sopka and Zavaritskogo volcanoes in 1947 and 1956. As a result the absence of mountain pine, bamboo, stone birch is observed, in spite of a fact that these are typical for Simushir Island. Alder groves with mosses and ferns are dominating on the island. Bamboo meadows and stone birch groves appear in around Dushnaya Bay to the north from Prevo volcano, while mountain pine thickets grows only on the western slopes of Ikanmikot volcano. These vegetation communities occupy bigger areas in the northern part of the island. It is possible, that discharged slaggy material had led to the replacement of stone birch, mountain pine and bamboo groves with alder forest.

\section{Conclusions}

Physico-geographic structure of the Kurile Islands is highly diverse what is determined by considerable meridional outstretch of the archipelago, transitional location between ocean and continent, monsoon circulation of air masses, and complicated system of sea currents. These islands are natural ecotone between the islands of Hokkaido and the Kamchatka Peninsula. The vegetation of the Kurile Islands occupy intermediate position and have a combination of features of the abovementioned regions.

Special traits of this archipelago are determined by the volcanic activity, which does not only lead to the formation of unique geomorphological appearance and its rapid change, but also to the considerable deformation of vegetation.

One of the actual scientific problem - it is identify the peculiarities of the development, dynamics and natural stability of the natural territorial complexes. Natural condition peculiarities of Kurile Islands, which are determined by location in transition zone between ocean and continent, their isolation, active geodynamic and natural catastrophic processes, allow to analyze these problems. Further economic activity on the islands should be based on the consideration of local peculiarities of the environment.

\section{References}

Aprodov, VA 1982, Volcanoes, Mysl, Moscow.

Atlas of Sakhalin Province 1967, Division of Geodesy and Cartography of USSR Government, Moscow.

Barkalov, VYu \& Eremenko, NA 2003, Flora of Natural Reserve "Kurilesky" and Reserve "Minor Kuriles" (Sakhalin District), Dalnauka, Vladivostok.
Barkalov, VYu 2002, The Kurile Islands flora, Dalnauka, Vladivostok.

Belousov, AB, Belousova, MG, Grishin, SYu \& Krestov, PV 2003, 'Historical eruptions of Chikurachki volcano (Paramushir Is., Kurile Islands)', Volcanology and Seismology, no. 3, pp. 15-34. 
Dirksen, VG \& Dirksen, OV 2006, 'Dynamics of vegetation after catastrophic eruption 7600 years ago on Kamchatka', Botanic Journal, vol. 91, no. 5, pp. 674-692.

Egorova, IA \& Khomentovskiy, PA 1988, 'Mountain pine thickets as an indicator of volcanic activity', Volcanology and Seismology, no. 6, pp. 82-88.

Ganzei, KS 2008, 'Geosystems of the South and Middle Kurile Islands', Geography and Natural Resources, no. 3, pp. 90-95.

Ganzei, KS 2009, 'Landscape typology of the Kurile Islands', Vestnik of FEB RAS, no. 4, pp. 153-159.

Gladkova, GA \& Butovets, GK 1988, 'Forest volcanic soils of Kunashir Island', Eurasian Soil Science, no. 2, pp. 54-67.

Ivanov, AN 2005, 'Landscape peculiarities of North-West Pacifica Islands', Izvestiya of Russian Geographical Society, vol. 137 , no. 4 , pp. 48-54.

Manko, YI \& Sidelnikov, AN 1989, Volcanism impact on vegetation, FEB AS USSR, Vladivostok.
Newest and modern volcanism on territory of Russia 2005, Nauka, Moscow.

Razzhigaeva, NG Ganzey, LA Grebennikova TA et al. 2013, 'Holocene climatic changes and vegetation development in the Kuril Islands', Quaternary International, vol. 290-291, pp. 126-138.

Reference book on USSR climate. Sakhalinskya province 1966, Gidrometizdat, Leningrad.

Reference book on USSR climate. Sakhalinskya province 1968, Gidrometizdat, Leningrad.

Rybin, AV, Karagusov, YV, Izbekov, PE, Terentyev, NS, Gurynov, VB, Neal, C \& Dean, K 2004, 'Status of monitoring active volcanoes of the Kurilee Islands: Present and future', The 2nd International Conference on Volcanic Ash and Aviation Safety. June 21-24, 2004. Washington, USA, pp. 56-58.

Vlasova, GA \& Polyakova, AM 2004, Active energetic zone of ocean and atmosphere of north-west part of the Pacific Ocean, Dalnauka, Vladivostok. 